\title{
Community Participation in Drought Risk Management in Kilifi County, Kenya
}

\author{
Stephen Kioko Musimba ${ }^{1 *}$, Moses Machuki Maturi Otieno ${ }^{2}$, Dorothy Ndunge Kyalo ${ }^{2}$, Angeline \\ Sabina Mulwa ${ }^{2}$

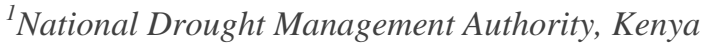 \\ ${ }^{2}$ University of Narobi, Narobi, Kenya
}

*Corresponding Author Stephen Kioko Musimba, National Drought Management Authority, Kenya

\begin{abstract}
Community participation is a vibrant constituent for successful disaster risk management recognized by the Sendai Framework for Disaster Risk Reduction. The African framework for ending drought emergencies emphasize the importance of local initiatives which are participatory, sensitive and gender focused in disaster risk management. Despite the deliberate efforts, the role of community participation in disaster risk management has remained glaringly unclear. This article focused on grassroots participation in resilience initiatives by examining practices in beneficiary identification, needs identification, information dissemination, ownership and control to describe their effects on the management of drought risk management. A descriptive study was conducted which noted weakness community participation role in design and implementation of resilience initiatives. The study established that the planning, design and implementation of drought risk management interventions was a preserve predetermined and dominated by experts. The study recommends integrated drought early warning for early, adequate and timely conveyance. Formation of community disaster management units would be implemented as a key pillar in productive community participation partnerships as community driver for drought risk planning and management. A break from the past was that men were a key segment of the community apparently left out in resilience building therefore there was need of developing attractive avenues for men participation. Technology transfer was identified as a key enabler of transformation which was very weak in the community. There was need to scale up extension services and civic education to promote uptake of new drought risk reduction technologies to elevate community livelihood productivity beyond subsistence.
\end{abstract}

Keywords: Beneficiary Identification; Community Participation; Disaster Risk Management; Needs Identification; Resilience Building

\section{INTRODUCTION}

Drought is a normal recurring climate feature in the world, which is among the earliest documented climatic events with adverse socio-economic impacts in the history of man after Noah's huge deluge (George, 2003; ISDR, 2009). Series of droughts in the $9^{\text {Th }}$ century in Sahel region among the ancient hunters and gatherers claimed lives, destroyed livelihoods and economies thereby outstripping the communities accumulated coping and adaptive capacities owing to low level preparedness and participation in drought risk management (ISDR, 2005; Mayell, 2002). Coerced community participation in drought risk reduction dating back to the times of Epic of Gilgamesh and biblical times of Joseph in Egypt yielded effective drought risk reduction. These classical accounts elaborates deliberate actions and predefined roles in community participation that were instituted to efficiently avert crisis. The actions taken characteristically maximized existing opportunities, knowledge and synergies in drought mitigation interventions considering appropriateness of needs, perceptions and existing capacities. (George, 2003)

Drought risk management system analyzes and manages the causal risk factors including reduction of exposure to drought, lessening individual vulnerability and property. Communities participate by taking part in any of the processes of formulation, passage, implementation and management of drought disaster risk management. This is watered down by the notion that drought affected population is too shocked, weak and helpless to take responsibility for their own survival. When given 
the opportunity survivors of drought shocks and hazards should find new strength during emergencies in the form of coping strategies for individual survivability. While it is imperative to force people to participate in initiatives which affect their lives, the public should be given the opportunity for participation as it was a basic human right and a fundamental principle of democracy. (ISDR, 2005; Goyet, 1999; Keen, 1994). Most risk disaster risk analysis processes involved external experts which undermined the participation of the rural communities. The ideal disaster risk management model indicates that communities build their own mechanism for goodwill and survivability which forms the basis of early preparedness and mitigation thereby attenuating drought risk. Community managed process was characterized by communities identifying and prioritizing their needs, planning activities, organizing strategies, leading implementation, coordinating efforts and evaluating drought disaster risk interventions (IIRR, 2011; ISDR, 2005).

The vulnerability of poor communities is exacerbated by geographical locations and time as they heavily depend on extraction of natural resources for their livelihoods which exist in relatively less prime areas. When drought strikes an area it causes the termination of livelihood factors and eventually closing in to threaten human lives limiting existence of alternative livelihood options. The less endowed citizens do not have the political influence to petition existing early warning system for failing to warn in advance. People are motivated to participate by being informed of what likely to happen and what to expect which has been undermined by unilateral declaration by project administration to external professionals. Communities participate in responding to questions administered by extractive risk assessors do not get the opportunity to prioritize needs or influence proceedings. In most cases the findings of the assessment are neither shared nor checked for accuracy by the community. The consultative principle holds that communities participate by being consulted, listened to and given feedback on their views ((Wilford, 1993; Bamberger, 1988; Reid, 2000).

When communities are not involved they hang around beliefs and experienced and hope for the best on the matters of drought risk management. Such involvement does not take place at the early stages of drought but rather after major drought episode has been experienced which make proactive drought mitigation untenable. The centrality of the role of community participation identifies the community not only as the primary beneficiary but also as the key actor of risk management. Empowered community provides meaningful participation in the whole process of risk management. The power and interest of most vulnerable members of the community, including men, women, children, youth, the elderly, people living with disabilities, terminally ill and other marginalized groups influences the effectiveness of disaster risk management. When the most vulnerable people have the chance to participate in risk analysis and management activities at local level they promote their own responsive capacity to disasters. Risk management revolve around reducing vulnerable conditions and the root causes of vulnerability to increase community's capacities, resources and coping strategies in order to avoid the occurrence of disasters in future. (IFRC, 2010; Schilderinck, 2009; UNICEF, 2008; Okoth, 2012; Patrick \&Akureje, 2012). Community initiatives were most effective where linkages were made with other community based organizations to allow sharing of information and experiences and encourage coordination of activities. (IFRC, 2011; Yonder, 2012; India, 2009). UNDP (2005) and IFRC (2011) agree that risk management at the local level was a key element to reduce disaster risks, building on the quality of community networks, the social fabric, and effective governance where the communities themselves undertook the majority of the activities that contributed to a safe and resilient community. This scenario points to the need to determine the role of community participation in drought risk management.

Droughts have become more frequent and severe over the recent years in Kilifi County leading to loss of livelihoods and threat to the lives of the populace. Various initiatives have been initiated to salvage the situation with minimal success rendering her food security status fragile (USAID, 2012; UNDP, 2005; Wilford, 1993; KFSSG, 2012, KFSSG, 2003; Okoth, 2012).Accordingly, this study sought to determine and describe the role of community participation in the implementation and management of drought reduction interventions in Kilifi County, Kenya.

The objectives of this study were to determine the role of community participation in beneficiary identification in drought risk management, to establish the role of community participation in needs identification in drought disaster risk management, to determine the role of community participation in information dissemination in drought disaster risk management and to establish the role of community participation in galvanizing community ownership and control in drought risk 
management in Kilifi County. The study tested the hypotheses that community participation played a role of identifying beneficiaries in drought risk management, Community participation plays a role of community needs identification in drought risk management, the role of Community participation plays a role of information dissemination in drought risk management and that community participation plays a role of galvanizing community ownership and control in drought risk management in Kilifi County.

\section{Material AND MethodS}

This study used descriptive survey research design using a sample of 200 respondents randomly selected to provide qualitative data. (Kothari, 2004;Ngulube, 2003). Key informant interviews were conducted with government staff and stakeholders. Questionnaires, interviews, and document analysis were used as the main tools for collection of data in this study to collect data on views, opinions, perceptions, feelings, attitudes, and facts. Descriptive statistics were used analyze the sample characteristics and the variables of the study.

\subsection{Theory}

The study is premised on the Arnstein's ladder of participation theory advanced Sherry Arnstein (Sherry, 1969). The theory elaborates levels of participation using the ladder analogy implying that participation grows from lower levels to higher levels depending on the mechanism of community engagement. This research identifies the gaps in citizen involvement that have caused increase in drought risk vulnerability at the expense of increased investments in mitigation efforts.

\section{Results}

The demographic findings indicate that male participation in the interviews was high (52\%) than that of women (48\%), owing to the fact that culturally men were freer than the women and easily accessible. Most respondents were the youth aged between 20-29 years and majority of respondents were literate having attained basic education. Most of the respondents (98\%) were aware that there were drought risk reduction initiatives which were mostly water harvesting investments (37\%) mostly implemented by NGOs (84\%) in Kilifi County. The study established that most participants in most of the community forums had low ownership and access to land resources. The study established that a higher proportion (59\%) of the community members was not individually involved in the identification of the interventions (Table A.1).

TableA.1. Involvement in selection of project beneficiaries

\begin{tabular}{|l|l|}
\hline \multicolumn{1}{|c|}{ Involvement in beneficiaries selection } & \multicolumn{1}{c|}{ Percent } \\
\hline Involved & 40.7 \\
\hline Not Involved & 59.3 \\
\hline Total & $\mathbf{1 0 0 . 0}$ \\
\hline
\end{tabular}

The study revealed that most drought disaster risk management interventions targeted women (63\%) whereas men were least targeted by the interventions (Table A.2).

TableA.2. Beneficiaries targeted by the interventions

\begin{tabular}{|l|l|}
\hline \multicolumn{1}{|c|}{ Beneficiaries targeted by the interventions } & \multicolumn{1}{c|}{ Percent } \\
\hline Everyone in the community & 16.6 \\
\hline Youth & 3.0 \\
\hline Widows & 2.5 \\
\hline PLWDs & 5.5 \\
\hline Elderly & 6.0 \\
\hline Men & 0.5 \\
\hline Women & 63.3 \\
\hline Widowers & 0.5 \\
\hline Others; Poor, Terminally ill and marginalized & 2.0 \\
\hline Total & $\mathbf{1 0 0 . 0}$ \\
\hline
\end{tabular}

The study revealed that most of the community members (47\%) were involved in beneficiary identification through their committees. The beneficiary identification exercise was heavily dominated by the dictates of the NGO staff $(26 \%)$ and the area chiefs' direction $(24 \%)$, whereas the youth participated the least $(1 \%)$ in beneficiary selection, which was also confirmed by the key informants 
and focus group discussions. Beneficiary selection was based on a number of factors where individual vulnerability was the most applied criteria (57\%) while connection with agency staff was the least considered factor. While the least community members (40\%) were individually involved in beneficiary identification most of the respondents $(68 \%)$ of them were satisfied with beneficiaries' identification process.

Table A.3shows that most of the respondents (57\%) felt that projects implemented under drought risk management were giving benefits after the donor agency exit and that community members were maintaining most of the initiatives $(70 \%)$ themselves.

TableA.3. Sustainability of drought disaster risk management interventions

\begin{tabular}{|l|l|l|l|}
\hline \multicolumn{2}{|c|}{ Sustainability element } & \multicolumn{3}{c|}{ Response as a Percentage of total Respondents } \\
\cline { 2 - 4 } & \multicolumn{1}{|c|}{ Agree } & \multicolumn{1}{c|}{ Disagree } & \multicolumn{1}{c|}{ Don't know } \\
\hline $\begin{array}{l}\text { Are the disaster risk management investments giving } \\
\text { benefits after the donor agency exit }\end{array}$ & 56.8 & 38.7 & 4.5 \\
\hline $\begin{array}{l}\text { Are the community members maintaining the } \\
\text { initiatives themselves }\end{array}$ & 70.4 & 26.6 & 3.0 \\
\hline
\end{tabular}

Chi-square test statistic to determine the relationship between community's participation and beneficiary identification was computed based on the alternate hypothesis that "Community participation does not play a role of identifying beneficiaries in drought risk management in Kilifi County", yielded the results in table A.4.

TableA.4. Chi-square test results on the role of community participation based on beneficiary identification.

\begin{tabular}{|l|l|l|l|}
\hline & Chi-Square Value & \multicolumn{1}{|c|}{ Df } & \multicolumn{1}{|c|}{ Asymp. Sig. } \\
\hline Who chose the beneficiaries & 278.231 & 6 & 0.000 \\
\hline Did you play a role in beneficiary identification & 8.447 & 1 & 0.004 \\
\hline $\begin{array}{l}\text { Were you satisfied with the way the beneficiaries were } \\
\text { identified }\end{array}$ & 25.332 & 1 & 0.000 \\
\hline
\end{tabular}

Chi square test results in Table A.4 above revealed that there was a significant role of community participation in beneficiary identification in drought risk reduction. At tabulated chi square critical levels, $\chi^{2}(6, N=199)=0.000, p=.005, \chi^{2}(1, N=199)=0.04, p=.005$ and $\chi^{2}(1, N=199)=0.00, p=$ .005 the research failed to accept the null hypothesis and concluded that community participation played a role of identifying beneficiaries in drought risk management in Kilifi County.

Most of the beneficiaries (60\%) participated in the selection of the drought risk management in the county while most of the community members did not feel the participation of the government authorities and its agents in drought risk management. The community identified the main role of the government as that of coordination of the implementation of the interventions. On the other hand the non-state actors mostly played the roles of implementation (46\%) and training (41\%) in drought risk management. The study established that needs assessment was majorly done by the dominant implementer of the drought mitigation initiatives who were mostly non state actors. Food security was identified as the most felt community need by the lead non state actors on to which a vehicle for redeeming the community from the vagaries of weather posed by drought was would be designed. There was great hope that food security initiative would be a panacea for drought risk reduction. During the process the drivers and contributing factors of food security ranked the least. The experts defined the food security system for Kilifi County as heavily rain depended and unpredictable. The interventions somehow addressed the food security needs of the community. The community felt more was desired in the way the projects were identified and implemented.

Chi-square test statistic to determine the relationship between community's participation and needs identification testing the alternative hypothesis that community participation played a role of community needs identification in drought risk management in Kilifi County yielded the results in table A.5.The Chi square test results in Table revealed that there was significant relationship between community participation and its role in community needs identification in drought risk reduction in Kilifi County. At tabulated chi square critical levels, $\chi^{2}(6, N=199)=0.68, p=.995 ; \chi^{2}(5, N=199)=$ $0.41, p=.995 ; \chi^{2}(4, N=199)=0.21, p=.995 ; \chi^{2}(3, N=199)=0.07, p=.995$ and $\chi^{2}(2, N=199)=$ $0.01, p=.995$ the research did not find sufficient grounds to accept the null hypothesis and concluded that community participation plays the role of community needs identification in drought risk management in Kilifi County. 
TableA.5. Chi-square test results on needs identification.

\begin{tabular}{|c|c|c|c|}
\hline Needs identification & Chi-Square value & df & Asymp.Sig. \\
\hline The interventions were community priority & 264.78 & 3 & 0.00 \\
\hline $\begin{array}{l}\text { Who identified the needs of the community during the project } \\
\text { initiation }\end{array}$ & 192.27 & 5 & 0.00 \\
\hline What needs were to be addressed by the intervention & 166.25 & 4 & 0.00 \\
\hline Did the interventions address the felt needs of the community & 132.04 & 3 & 0.00 \\
\hline Did the beneficiaries participate in the selection of the projects & 72.37 & 2 & 0.00 \\
\hline What is the role of the Government agencies in these projects & 85.70 & 4 & 0.00 \\
\hline What was the role of the NGOs & 341.90 & 6 & 0.00 \\
\hline Did you play a role in needs identification & 161.54 & 3 & 0.00 \\
\hline Were you satisfied with the way the needs were identified & 130.59 & 3 & 0.00 \\
\hline
\end{tabular}

Most community members (52\%) depended on their administrators for drought information sharing. The local political leaders were very vocal members of the community who in the converse were unpopular in sharing drought early warning information as illustrated in table A.6. The local administrators were respected by the community and were believed to abhor accurate and timely information on all matters pertaining the community while the politicians camouflaged to fit situations. The drought early warning system document was a special publication that was distributed to the community monthly for the purposes of timely and accurately informing the community about drought status. This bulletin reached only a few members of the community who did not take the document seriously and more often than not undermined the information. Drought early warning system was taken as a reserve for National Drought Management Authority and observed as a tool for drought response due to the fact that it identified the actions to be taken at different drought phases.

TableA.6. Drought risk Information sharing

\begin{tabular}{|l|l|}
\hline \multicolumn{1}{|c|}{ Source of Information } & \multicolumn{1}{c|}{ Percent } \\
\hline Friends & 30.2 \\
\hline NGO staff & 12.1 \\
\hline The chief & 51.8 \\
\hline GoK staff & 3.5 \\
\hline Politician & 1.0 \\
\hline Public Notices & 1.5 \\
\hline Total & 100.0 \\
\hline
\end{tabular}

Table A.7: shows most community members (69\%) were not initially involved in planning and design of drought risk management interventions, $88 \%$ did not have access to the project budgets, $91 \%$ did not have knowledge of the budgets, $84 \%$ were aware of the benefits of the projects and $57 \%$ were targeted by the interventions. The community members were not involved in the budgeting process and in the few cases they were involved there was high level of non-disclosure which kept the community in the dark in appreciating the resource envelope. This makes it a challenge for the community to make commitments on the part of the community contribution as well as costing their contributions to the interventions. The community feedback system is dominated by the implementing agencies hence ganging the community voices and choices.

TableA.7. Community involvement in intervention planning and design

\begin{tabular}{|l|l|l|}
\hline \multicolumn{1}{|c|}{ Community involvement at planning and design } & \multicolumn{2}{l|}{ Responses as percentage of total Respondents' } \\
\hline & Yes & No \\
\hline Involved in the intervention planning and design? & 31.2 & 68.8 \\
\hline Access to the projects budget? & 11.6 & 88.4 \\
\hline $\begin{array}{l}\text { Did you know the amount of money invested in these } \\
\text { interventions? }\end{array}$ & 9.5 & 90.5 \\
\hline $\begin{array}{l}\text { Do you have information about benefits of the } \\
\text { interventions? }\end{array}$ & 84.4 & 15.6 \\
\hline Were you targeted by this intervention? & 56.8 & 43.2 \\
\hline
\end{tabular}

Chi-square test statistic to determine the relationship between community's participation and information dissemination testing the hypothesis that Community participation played a role of information dissemination in drought risk management in Kilifi County yielded the results tabulated in table A.8.The test revealed the information that at $\chi^{2}(6, N=199)=0.68, p=.995 ; \chi^{2}(5, N=199)=$ 
$0.41, p=.995 ; \chi^{2}(3, N=199)=0.07, p=.995 ; \chi^{2}(2, N=199)=0.01, p=.995$ and $\chi^{2}(1, N=199)=$ $0.00, p=.995$ which does not provided sufficient evidence to support the null hypothesis hence the alternative hypothesis that community participation plays a role of information dissemination in drought risk management was accepted.

Table A.8. Chi square test results on the role of community participation based on information dissemination

\begin{tabular}{|c|c|c|c|}
\hline Test Statistics & Chi-Square & df & Asymp. Sig. \\
\hline How did the information about intervention get to you? Through & 248.65 & 5 & 0.00 \\
\hline Were you involved in the intervention planning and design & 28.27 & 1 & 0.00 \\
\hline Do you have access to the projects budget & 117.63 & 1 & 0.00 \\
\hline Did you know the amount of money invested in these interventions & 130.26 & 1 & 0.00 \\
\hline Do you have information about benefits of the interventions & 94.32 & 1 & 0.00 \\
\hline Were you targeted by this intervention & 3.66 & 1 & 0.06 \\
\hline Do you know why you were targeted by this intervention & 54.91 & 2 & 0.00 \\
\hline Do you know why the project came to this area & 220.02 & 2 & 0.00 \\
\hline Where do you get drought early warning information from & 322.58 & 5 & 0.00 \\
\hline $\begin{array}{l}\text { Does the community in this area have forums to discuss on Disaster } \\
\text { risk management }\end{array}$ & 127.65 & 3 & 0.00 \\
\hline $\begin{array}{l}\text { Who gives feedback about the deliberations of the community on } \\
\text { Disaster risk management activities }\end{array}$ & 250.79 & 6 & 0.00 \\
\hline Is the feedback timely & 45.15 & 2 & 0.00 \\
\hline Is the feedback adequate & 38.12 & 2 & 0.00 \\
\hline $\begin{array}{l}\text { Have you ever been involved in negotiations and discussions about } \\
\text { Disaster risk management interventions in this area }\end{array}$ & 88.41 & 2 & 0.00 \\
\hline $\begin{array}{l}\text { During the negotiations were you allowed to make your } \\
\text { Contributions }\end{array}$ & 75.39 & 2 & 0.00 \\
\hline
\end{tabular}

The study, through focus group discussions, confirmed that the beneficiaries of the drought risk reduction projects were selected based on criteria determined by the donors and the implementers of the interventions and the communities were not given the opportunity to discuss and amend the criteria. In most of the cases, the local administration was sensitized beforehand on the requirements by the implementers and lead in influencing the community. Most organizations had predetermined mandates and only targeted a certain cadre of beneficiaries in the community and as a result, community participation was used as a rubber stamp for predetermined beneficiary criteria.

It was also confirmed that community needs identification was carried out through assessments, which involved them passively. Some interventions were mooted by the administrative and political leaders, which were not priorities of the community. In fact, drought risk management was used as an instrument of political power, which elicited a lot of political influence among the community members sometimes at the expense of community participation. Normally chiefs shared information with the community in form of advertisements during public meetings. There was little or no feedback on drought early warning information and community members depended on weather forecast information broadcast through radio, which was very global. It was also confirmed that there were no forums to discuss drought risk reduction at the community level. The respondents confirmed that they were not involved in the actual design and planning of drought risk reduction and were not privy to the project budgets.

The findings confirmed that community participation played a very insignificant role in galvanizing control and ownership of the projects. The FGD pointed out that quite a number of Government and donor-funded projects could not continue giving the same benefits after phases out. A few community-funded projects sprung up in the county but soon met their eventual death when political influence and corruption thwarted them.

\section{DISCUSSION}

This study sought to determine role of community participation in drought risk management in Kilifi County. The study revealed that majority of the community members were not individually involved in the selection of the interventions and the design of the beneficiaries selection criteria of drought risk management. This confirms what Gladwell (2000) termed as an idea in good currency that community participation in beneficiary identification was by name but not practice and the communities were only involved in implementing a pre-set criteria. While Shileche (2012) 
emphasizes that effective disaster risk management was because of effective community participation role in identifying beneficiaries, interests, expectations and influence, the study reveals that there was predetermined criteria for beneficiary identification and the communities passively participated in effecting it. The study confirmed the argument by World Bank, FAO \&IFAD (2009) that drought disaster struck communities in their local setting and hence commanded a lion's share as planners, implementers, partners, and leaders of disaster risk management built on the interests of the most vulnerable community members as most of the interventions targeted women and other vulnerable groups. However, community members were involved in beneficiary identification through community committees constituted in the presence of the administrators where the NGOs and the chiefs influenced the selection of beneficiaries constricting community participation role. Although most of the beneficiaries targeted were the most vulnerable people, they were not practically involved in design of the identification and selection criteria. Most of the community members were not involved in beneficiary identification but most of them were satisfied with the selection criteria. A Chi-square test statistic revealed that community participation played a role of beneficiary identification in drought risk management interventions in Kilifi County confirming the claim made by ABS (2004) that coerced community participation yielded faster results which falls in the lowest rung of the Arnstein's ladder of therapy and manipulation in community participation.

The study revealed domination of community needs identification by the influence from external experts and professionals although done in the presence of the community members. IISD (2007) argues that it was at the community level where disaster effects were felt most and community participation would play a very important role in needs identification. The results of the study confirmed the observation by IFRC (2011) that the community would undertake needs identification and goal determination contributing to safe and resilient community. The findings revealed that the project implementers who were majorly NGOs undertook the role of criteria determination for needs identification, implementation, and training of the communities, which defies the Hyogo framework for action, which acknowledged that both communities and local authorities had a role to play in needs identification for successful disaster risk management. Scott (2001) explains that community power involves deep acceptance of one another, complete inclusiveness and self-awareness which enables the community to understand itself better in terms of the circumstances that it finds itself in. World Bank (2010) confirms that the community offers each member the safety of knowing that they are accepted for whom they are and bring forth the best person can offer because they know their gifts of time, talent and ideas are acceptable. The study indicated that although the donor package in many cases did not require community contribution and assistance in technical description of needs, effective drought risk management needs profiling of the capacities of the communities. Most of the interventions were able to address the needs of the community and the youth were engaged in interventions which had monetary gains confirming the claim by Kenya (2007) that most of the youths were unemployed. The study revealed that there was significant relationship between community participation based on community needs identification and confirmed that there was a role of community participation in needs identification in drought risk management.

The establishment of disaster information system characterizes effective drought risk management, which is sensitive to the needs of the community. The study revealed that most of the community depended on the chiefs for information, not initially involved in planning and design of drought risk reduction, did not have access to the project budgets, did not have knowledge of the budgets and knew the benefits of the projects. The study revealed that most of the community received drought information feedback that was inadequate and untimely and confirmed that community participation would have a role of information dissemination in the management of drought disaster risk management interventions only if the information was available at the community level.

Adato (2005) argues that instrumentalist foundation involving recognition that top-down, technocratic forms of development imposed on diverse local realities often resulted in project failure. The study revealed that control of interventions was dictated from above and the community were passive recipients. The youth were least involved in the control of drought disaster risk management interventions, the communities contributed labour towards the implementation of interventions and few interventions were funded by the community. Abrams (1971) argues that local community should be given an active role in the control of their interventions in order to own them and proposes that it were rational to give control of affairs and decisions to the people most affected by them. 
Communities own initiatives were heavily funded by the community where more emphasis was made in village loans and savings association unlike the non-financial drought risk reduction. The study revealed that there was a weak role of community participation in control of drought risk reduction.

\section{CONCLusions}

Role of community participation in drought risk management is very important to the success and sustainability of the initiatives. The people and the community organizations inhabiting a particular local setup must be involved in considering their interests, appreciating the damages and the shocks caused by drought. Community members should be individually and collectively involved in making decisions and setting up the criteria for beneficiary selection in hazard profile analysis. During the assessments and data collection exercises, community members should be involved for them to provide key information that would aid project design. Effective disaster risk management was because of effective community participation role in recognizing the existing variations in endowments, interests, expectations and influence of individuals and groups in the community. In the dispensation of the new constitution in Kenya, which holds the supremacy of the people paramount where, predetermined criteria for beneficiary identification that involve communities passively was unconstitutional. Drought disaster struck communities in their local setting and the communities commanded a lion's share as planners, implementers, partners and leaders of disaster risk management built on the interests of the most vulnerable individuals and groups in the community. Community committees play a significant role in organizing and interpreting the language and concepts of the experts during the design and planning of drought risk reduction therefore proper and democratically constituted community units would assist all stakeholders in all stages of the initiatives. Community participation was critical in needs identification because it was at the community level where disaster effects were felt the most and needs identification and the community would undertake goal determination contributing to safe and resilient community. Project implementers should facilitate communities and become learners of change as stipulated by the Hyogo framework for action. Community participation has power that involves deep acceptance of one another, complete inclusiveness and self-awareness. This enables the community to understand itself better in terms of the circumstances affecting their livelihoods and offers each member the safety of knowing that they are accepted for whom they are and bring forth the best they can offer because they know their gifts of time, talent and ideas. Donors should redesign their project packages to include community contribution of ideas, materials and assistance leading to profiling of community capacities. The establishment of disaster information system characterizes effective drought risk management, which is sensitive to the needs of the community that adequately gives information and feedback to the community. It was plausible that drought risk reduction usurped huge budgets, which were not accessible by the community. Local community should play an active role in the control of their interventions since it was rational to give control of affairs and decisions to the people most affected by them. Communities own initiatives were heavily funded by the community where more emphasis was made in village loans and savings association unlike the non-financial drought disaster risk management because to was appalling and had a quick turnaround time to the community.

\section{RECOMMENDATIONS}

This study recommends that the community, planners, professionals and the implementers of drought disaster risk management need to realize and rise to the awakening that drought affected people have the learning and the strength to develop coping and survivability capacities. The county and national governments should play a leading role in coordinating drought risk reduction to ensure that the basic fundamental rights of the citizens are guarded and upheld. The government agencies need to take a leading role in civic education and develop a common public engagement framework that recognizes the role of community participation to synergize the ambitions of the development partners to make them fruitful.

There is a need to enhance community communication and feedback mechanism in the county. The county information and communication infrastructure was wanting and the available channels of communication do not effectively deliver information to the communities. The county government needs to encourage public-private partnership in establishing local media station that effectively gives information to the communities. There is also a need for the development agencies to scale up extension services in the area through community based technical assistants to promote uptake of new drought risk reduction technologies to elevate community livelihood productivity beyond subsistence. 
There is a need to educate men and youth to get involved in drought risk reduction without leaving only women to participate. Developmental agencies and the government need to create awareness among the male population on the importance of participating in drought risk reduction.

In order to sustain the efforts so far realized in community participation it is necessary to improve community drought early warning system, as it was necessary for the success of the initiatives in the county. There is need to set up an integrated drought early warning stations fully furnished with facilities so that many people can get drought warning information early, timely and adequately. Development partners need to assist the county to form community committees on disaster risk management at the sub counties and train them adequately to become community drivers of drought disaster risk management planning and management.

It is evident from the study that it is necessary to conduct further studies to identify the role of devolved governance on drought risk reduction. Further studies should deeply evaluate the metrics of successful community participation on disaster risk management. It is necessary to evaluate the effects of indigenous drought early warning systems on drought risk management in the advent of climate change.

\section{ACKNOWLEDGEMENTS}

I wish to thank the Almighty God for His favour and grace, may His name be praised! I am indebted to Dr. Moses Otieno, Dr. Dorothy Kyalo and Dr. Angeline Mulwa for their guidance and technical direction during the conceptualization, formulation and drafting of this study. I am grateful for their efforts and dedication in reflecting, reading, encouraging, and most of all patience throughout the entire process. My heartfelt gratitude goes to Dr. Johnbosco Kisimbii, who relentlessly offered scholarly guidance that motivated the conception of this study. I would like to appreciate and thank Mr. Cornel Ndombi for the productive discussions and engagement that provided very useful information that motivated this research.

I am grateful to the unwavering support of Paul Kimeu, Ms. Scholastica Musyoka, Margaret Kahigaand Kawthar Mohamed who offered useful background information that formed the basis of this study. I wish to acknowledge Keiko Temura of Save the Children Japan for her productive discussions and ideas that inspired the genesis of this paper. I wish to express my gratitude to my research assistants Mr. Martin Nyamawi Kazungu, Ms. Deborah Shichei Mulobi, Ms. Winnie Chimea Masera, and Ms. ShellmillObuyaOkeyoin overcoming unfriendly weather conditions during field data collection. Last but not least, I wish to register my appreciation my wife, There sia Ndunda and my son, Moffat Kioko for their moral support, encouragement and patience during the study.

\section{REFERENCES}

[1] Abola, C. et al. (2008). Outcome and Impact Evaluation of the UN World Food Programme Food for Assets Interventions in the Sub-Regions of Acholi. Karamoja and West Nile, Uganda.

[2] Abrams, C. (1971). The language of cities: a glossary of terms. New York: The Viking Press.

[3] ABS (2004) Crime and Justice: Women in Prison, Australia.

[4] Acacia. (2010). Recommendations for an Institutional and Operational Framework for the Implementation of PRRO 10666 K. Final Draft Report. Protracted Relief and Recovery Operations (PRRO). Nairobi, Kenya: Acacia Consultants Ltd.

[5] Adams, M. E. (1986). „Merging Relief and Development: The Case of Turkana“, Development Policy Review (4):314-324. Kenya.

[6] Adato, M., Hoddinott J. and Haddad L. (2005). Power, Politics, and Performance; Community Participation in South African, Public Works Programs, Research Report. Washington, D.C, USA: International Food Policy Research Institute.

[7] ADCL. (2008). Water harvesting for improved drought preparedness using FFA: Conceptual Framework for ASAL Development. Report for World Food Programme. WFP, Nairobi.

[8] Ahmeda, Z. (2013). Disaster risks and disaster management policies and practices in Pakistan: Acritical analysis of Disaster Management Act 2010 of Pakistan, International Journal of Disaster risk management. Queen Mary,University of London, UK.

[9] Akumu, O. (2007). Towards effective governance of water services in Kenya. Journal Water Policy 9: 529-543. Kenya.

[10] Alliance Development Works. (2012). World Disaster risk Report 2012: Together for people in need. USA 
[11] Apthorpe, R. et al. (1996). Protracted emergency relief food aid: towards productive relief. Programme policy evaluation of 1990-1995 period of WFP-assisted refugee and displaced persons operation in Liberia, Sierra Leone, Guinea and Cote d'Ivoire. Rome: World Food Programme.

[12] Arnstein, S.R. (1969). A ladder of citizen participation. Journal of the American PlanningAssociation, Vol. 35, No.4 1969, pp. 216-224. USA.

[13] Aytenew, Birhanu and Aylieff, J. (1993). Inventory, Map and Analytical Review of Food and Cash-for- Work Projects in Ethiopia, WFP Food for Development: Discussion paper No. 3, Rome: World Food Programme.

[14] Bamberger, M. (1988). The Role of Community Participation in Development Planning and Project Management. Washington D.C. USA: Economic Development Institute of the World Bank.

[15] Barrett, B. and Clay, D. (2003). Self-targeting accuracy in the presence of imperfect factor markets: evidence, from food for work in Ethiopia. Journal of Development Studies, Vol. 39, No. 5. Rome: World Food Programme.

[16] Barrett, C., Holden S. and Clay D. (2004). Can Food For Work Programmes Reduce Vulnerability: Discussion Paper? Norway: University of Norway

[17] Barrett, C.B. and Carter, M.R. (2005). The Economic of Poverty Traps and Persistent Poverty: As AssetBased Approach. Rome.

[18] Baser, H. and Morgan, P. (2008). Capacity, change and performance: Study report, Discussion Paper 59B, European Centre for Development Policy Management, Maastricht.

[19] Bazarragchaa, S. (2012). Community participation in disaster risk mitigation: a comparative study of Mongolia and Japan. Mongolia: Disaster Research Institute.

[20] Bennell, P. (2007). Promoting Livelihood Opportunities for Rural Youth. IFAD.

[21] Benson, C. and Clay, E. J. (1986). Food aid and food crisis in Sub-Saharan Africa: Statistical trends and implications. UK.

[22] Benson, T. (2003). Applications of Poverty Mapping to World Food Programme Activities in Malawi. Rome.

[23] Bernahu, D. (1993). Monitoring and Evaluation Framework for the Employment-based Safety-net Pilot Projects. Rome: World Food Programme

[24] Bezuneh, M., Deaton, B. and Zuhair, S. (2003). Food Aid Disincentives: the Tunisian Experience ${ }^{e e}$, Assistance for Relief and Recovery of Refugees, Displaced Persons and Vulnerable Groups. Tunisia.

[25] Birner, R. (2007). Choosing Policy Instruments to Reduce Poverty and Hunger. In 2020 Focus Brief on the World's Poor and Hungry People. Washington D.C.

[26] Brisson D., Roll S. (2008) An Adult Education Model of Resident Participation: Building Community Capacity and Strengthening Neighborhood-Based Activities in a Comprehensive Community Initiative (CCI), University of Denver.

[27] Bryson J. M. (2004). What to do when stakeholders matter, Stakeholder Identification Analysis Techniques. Minneapolis, USA: University of Minnesota.

[28] Buchanan, Smith, M. and Maxwell, S. (1994). Linking relief and development: an introduction and overview, IDS Bulletin, vol. Vol. 25, No. 4.

[29] Buckles, R. (1988). Food Targeting in Darfur: Save the Children Fund's Programme in 1986 ${ }^{\circ e}$ Disasters $12(2): 97-103$.

[30] Burns, D. et. al. (2004). Making community participation meaningful; A handbook for development and assessment. University of West England, UK: The Policy Press.

[31] Clay, E.J. (1986). Rural public works and food-for-work: A survey. World Development 14(10):1237-1252.

[32] Colin, H. D. et al. (2007). Truths and myths about community participation in post-disaster housing projects. Habitat International, Volume 31, Issue 1, March 2007, Pages 100-115 Collins, G. (2011). Foodfor-Work and Food-for-Assets: What ${ }^{\text {ee }}$ s the Difference? Technical Brief, FFP commissioned report for the World Food Programme, USAID EA.

[33] De, U.S., Dube R.K. and Rao G.S. P. (2005) Extreme Weather Events over India in the last 100 years University of Pune, India Delhi . Vol.9, No.3, pp.173-187

[34] Diang'a, E. and Ngigi, S. (2009). Review and Appraisal of WFP Food for Assets (FFA) Programme in Kenya, 2004-2009. Nairobi: WFP

[35] Finsterbusch, K and Van Wicklin, W. I. (1987). The contribution of beneficiary participation to development project effectiveness. University of Maryland Massachuserrs institute of Technology, Maryland.

[36] Frankenberger, T. et al (2007). Sudan Food Assistance Strategy: FANTA project, USAID and TANGO.

[37] Gentilini, U. (2007). Cash and Food Transfers: A Primer. Occasional Paper No. 18, WFP.

[38] George, A. R. (2003). The Babylonian, Gilgamesh Epic: Critical Edition and Cuneiform Texts. England: Oxford University Press; available online. http://www.mechon-mamre.org/p/pt/pt0141.htm, accessed 20Th April 2013. 
[39] Gero, A., M'eheux, K. and Dominey-Howes D. (2011) Integrating community based disaster risk management and climate change adaptation: examples from the Pacific, Australian Tsunami Research Centre and Natural Hazards Research Laboratory. University of New South Wales, Sydney, Australia.

[40] Gibbons, A. (1993). Howthe Akkadian EmpireWas Hung Out to Dry, Science Journal 20 August 1993 : 985. [DOI:10.1126/science.261.5124.985]

[41] Gilligan, D.O. and Hoddinott, J. (2007). Is There Persistence in the Impact of Emergency Food Aid? Evidence on Consumption, Food Security, and Assets in Rural Ethiopia, American Journal of Agricultural Economics 89 (2):225-242.

[42] Gladwell, M. (2000) The tipping point. How little things can make a big difference little brown and company, New York.

[43] Goyet, C. V. (1999). Stop propagating disaster myths, disaster preparedness and emerging response association. DERA Newsletter. Denver, USA.

[44] Gragne, K. (1993). Food Aid Monetization in Ethiopia, Food-for-Development Discussion Paper No. 6. Rome.

[45] Haan, N., Nisar M. and James, D. (2006). A Review of Emergency food Security assessment practice in Ethiopia: HPG Research Report. Rome: World Food Programme.

[46] Haddad, L. and Adato, M. (2001). How efficiently do Public Works Programs Transfer Benefits to the Poor? Evidence from South Africa: Discussion Paper. Washington DC: IFPR.

[47] Haddad, L. and Frankenberger T. (2003). Integrating Relief and Development to Accelerate Reduction in Food Insecurity in Shock-Prone Areas, USAID.

[48] Hayes M., Knutson C., and Hu S. Q. (2005). Multiple-Year Droughts In Nebraska, University of Nebraska-Lincoln, Nebraska.

[49] Heagney, J. (2012). Fundamentals of Project Management. $4^{\text {Th }}$ Ed. New York: American Management Association.

[50] ICRH. (2008). Moving the Goal Posts Baseline Evaluation Report. Kilifi, Kenya

[51] IED. (2011). Hand book on provisions on Governance structure and elections in the constitution of Kenya. Kenya National Civic Programme. Institute for Education in Democracy, Nairobi.

[52] IFAD. (2007). Gender and Water: Securing water for improved rural livelihoods: The multiple uses system approach. IFAD.

[53] IFRC. (2010). Desk review on trends in the promotion of community-based disaster risk management through legislation: Background paper for the ISDR Global Assessment Review. Geneva.

[54] IFRC. (2011). Key determinants of a successful CBDRR programme; Community Based Disaster risk management Study. ARUP International Development, Geneva. Available online http://www.ifrc.org. Accessed 15/4/2013.

[55] IIRR. (2011). Report on community managed disaster risk management (CMDRR) customized course for COOPI staff and partners. Mandera, Kenya.

[56] IISD (2007) The Sustainable Development Timeline; Silent Spring, $5^{\text {Th }}$ Edition.

[57] ILO and KNBS. (2012). Kenya Child labour baseline survey: Kilifi District report. Nairobi, Kenya.

[58] ILO. (2012). Kenya labour market survey for older children withdrawn from worst forms of child labour: Kilifi district report. Nairobi, Kenya.

[59] India, Government of. (2009). Manual for Drought Management Department of Agriculture and Cooperation, Ministry of Agriculture, New Delhi, India.

[60] ISDR (2005) Building the Resilience of Nations and Communities to Disasters, World Conference on Disaster Reduction, 18-22 January 2005, Kobe, Hyogo, Japan; Extract from the final report of the World Conference on Disaster Reduction (A/CONF.206/6), www.unisdr.org/wcdr.

[61] ISDR. (2009). Hyogo Framework for Action 2005-2015: Building the Resilience of Nations and Communities to Disasters. Geneva.

[62] Israel, D.G. (2009). Sampling issues, non-response. University of Florida.

[63] Keen, S. (1994). Hymns to an Unknown God: Awakening the Spirit in Everyday Life. New York: Bantam Books.

[64] Kenya, Government of (2008), Kenya Vision 2030, First Medium Term Plan 2008-2012; Towards a globally competitive and prosperous Nation. Ministry for Planning, National Development and Vision 2030, Nairobi.

[65] Kenya, Government of and UoN. (1988). Kilifi District Social Cultural Profile. Ministry of Economic Planning and National Government, Nairobi, Kenya.

[66] Kenya, Government of, (2004). Draft National Disaster Management Policy. Nairobi, Kenya. Kenya, Government of, (2004). Kilifi District Poverty Reduction Strategy Paper: Consultation

[67] Report for the period 2001-2004. Ministry of Finance and planning, Nairobi, Kenya. Kenya, Government of, (2007). Draft National Social Protection Strategy. Ministry of Gender, Sports, Culture and Social Services, Nairobi. 
[68] Kenya, Government of, (2007). National Policy for the Sustainable Development of Arid and Semi-Arid Lands of Kenya. Office of the President - Special Programmes, Nairobi

[69] Kenya, Government of, (2008) Kilifi District Development Plan (2008-2012). Ministry of Finance and planning, Nairobi, Kenya.

[70] Kenya, Government of, (2016). Kilifi County 2012/2013 - 2014/2015 MTEF Budget stakeholders ${ }^{\text {ce }}$ consultation Report. Ministry of Finance, Nairobi, Kenya.

[71] Kenya, Government of. (2007). Kenya Vision 2030: A Globally Competitive and Prosperous Kenya, Nairobi.

[72] Kenya, Government of. (2009). Agriculture Sector Development Strategy (ASDS): 2009- 2020.Ministry of Agriculture, Nairobi.

[73] KFSSG (2003). The 2002/2003 Long rains Food security Assessment Report, Kenya.

[74] KFSSG (2012). The 2011/2012 Short rains Food security Assessment Report, Kenya.

[75] KNBS (2009). Kenya National Population and Housing Census: Coast Province Summary ofCensus Results (Volume I \& II). Nairobi, Kenya.

[76] Kothari C.R. (2004). Research Methodology,Methods and Techniques. New Delhi, India: NewAge International $(\mathrm{P})$ Ltd.

[77] LeDe, L., Gaillard, J.C. and Friesen W. (2013). Remittances and disaster: A review. International Journal of Disaster risk management, The UniversityofAuckland, New Zealand

[78] Lovell, R. (1992) Citizen "es charter: the cultural challenge, public administration. Vol. 70 Sheffield.

[79] Mainlay, J. and Tan, S.F (2012) Mainstreaming gender and climate change in Nepal. IIED Climate working paper No. 2, November 2012.

[80] Mayell, H. (2002, October). Ancient Chile Migration Mystery Tied to Drought. National Geographic News newspaper, October 24, 2002.

[81] Moser, C. (1989). Gender planning in the Third World: Meeting practical and strategic gender needs. World Development.

[82] Mugenda O. M. \&Mugenda, A. G. 1999). Research methods: quantitative and qualitative approaches. Nairobi: ACTS Press

[83] NCCS. (2012). Guidelines for child participation in Kenya. Nairobi, Kenya

[84] NCLR (2010) Kenya Law Reports; The Constitution of Kenya, 2010, Published with the Authority of the Attorney General, Kenya. www.kenyalaw.

[85] Norton, A., Conway, T. and Foster, M. (2002). Social Protection: Defining the Field of Action and Policy. Development Policy Review 20 (5):541-567.

[86] Okoth, J. (2012). Factors influencing sustainability of community based projects: the case of Arid Lands Resource Management Project II in Ganze Sub County, Kilifi County, Kenya. Masters Dissertation. University of Nairobi, Kenya.

[87] Okubo, D. (2000). The community visioning and strategic planning handbook. Denver, Colorado: National Civic League Press

[88] Okubo, D. (2000). The Community Visioning and Strategic Planning Handbook, National Civic League Press Denver, Colorado.

[89] Ondicho T. G. (2012) Local Communities and Ecotourism Development in Kimana, Kenya Massey University, New Zealand, Journal of Tourism, Volume XIII, No.1, 2012

[90] Onsomu E. N., et al. (2004) Community schools in Kenya; Case study on community participation in funding and managing schools, International Institute for Educational Planning UNESCO, France

[91] Oxfam (2011) Briefing on the Horn of Africa Drought: Climate change and future impacts on food security, UK.

[92] Patrick, L. K. and Akureje, N. O. (2012). Evaluation Report for Community Managed Disaster risk management Intervention: Approach and Methodology Employed in Karamoja Region. DanChurchAid, Kampala, Uganda.

[93] Rami, H. (2002). Food aid is not development: Case studies from North and South Gonder, Ethiopia. UN Emergencies Unit, Ethiopia.

[94] Reason, P. (1998). Political, Epistemological, Ecological and Spiritual Dimensions of Participation. Studies in Cultures, Organizations and Societies. England.

[95] Reid, J. N. (2000). Community Development: How People Power Brings Sustainable Benefits to Communities. USDA Rural Development.

[96] Routledge. (2012). Conservation and sustainable development: linking practice to policy in Eastern Africa. International Development Research Centre, Canada. 
[97] Schilderinck, G. (2009). Drought Cycle Management in arid and semi-arid Kenya: A relevant disaster risk management model? An empirical study of Garissa, Marsabit, Samburu and Wajir. Catholic Organization for Relief and Development Aid, Hague.

[98] Schon D. A. (1971) Beyond the Stable State, USA

[99] Scott, M. P. (1998). The Different Drum: Community Making and Peace. New York:

[100] Shileche, M. (2012). How can oil tanker fire disasters in Kenya be mitigated through community based disaster management approaches? Unpublished master's dissertation. Oxford Brookes University.

[101] Skidmore, P., Bound, K. and Lownsbrough, H. (2006). Community participation, who benefits? Spring K., Dietz N. and Grimm, R. (2007) Youth Helping America Leveling the Path to Participation: Volunteering and Civic Engagement Among Youth From Disadvantaged Circumstances; Corporation for National and Community Service, USA.

[102] Today (2013) It's drought, not floods Singapore should fear, University of Singapore, Today magazine 18 march 2013 pp 10\&12Touchstone Books. The epic of Gilgamesh Assyrian International News Agency, Books Online: http://www.aina.org/books/eog/eog.pdf; Retrieved on 20Th April 2013

[103] UNDP (2005). Women and Water: Women 2000 and beyond series. United Nations, Ward for the Advancement of Women- Department of Economic and Social Affairs. Geneva.

[104] UNDP. (2012). Step up women and girls; the invisible force of resilience: International day for Disaster Reduction, Schools Art Painting and Essay competition. Nairobi Kenya.

[105] UNICEF. (2008). Community-based Disaster risk management: Conference proceedings. Kolkata, India

[106] UNISDR and UNOCHA. (2008). Disaster Preparedness for Effective Response Guidance and Indicator Package for Implementing Priority Five of the Hyogo Framework. Geneva, Switzerland

[107] USAID (2012) Gender Equality and Female empowerment Policy, Washington DC. Wanninayake W.M.S.B. (2011) A preliminary study of the drought mitigation practices of agriculture sector in Japan and looking for possibilities to apply best practices to Sri Lanka, Research Report, Sri Lanka

[108] WFP Uganda. (2005). WFP'e s development and recovery portfolio in Uganda: Evaluation Report.Rome.

[109] WFP. (2003). Enhanced Commitment to Women to ensure Food security: WFP Gender Policy 2003 2007. Rome.

[110] WFP. (2004). WFP West Africa Coastal Region Protracted Relief and Recovery Operation Project: Final evaluation Report. Rome.

[111] WFP. (2008). Evaluation of WFP"es Gender Policy (2003-2007): Enhanced Commitments toWomen to Ensure Food Security. Rome: WFP.

[112] WFP. (2011). Promoting Gender Equality and the Empowerment of Women in Addressing Food and Nutritional Challenges. WFP Gender Policy and Strategy. Rome.

[113] Wilford, J. N.(1993, August). Collapse of earliest known empire is linked to long, harsh drought.August 24, 1993, The New York Times.

[114] Williams J. J. (2006) Community Participation; Lessons from post-apartheid South Africa Policy Studies, Vol. 27, No 3, 2006.

[115] World Bank, FAO and IFAD. (2009). Gender in Agriculture: Source Book. Washington DC: The World Bank.

[116] World Bank. (2008). Girlse Education in the 21st Century: Equality, Empowerment, and Growth. Washington, DC: The World Bank.

[117] World Bank. (2010). Natural hazards, unnatural disasters: The economics of effective prevention. Washington D.C.; The World Bank.

[118] Yonder, A. (2012). Community Participation in Disaster risk management: An analysis of Grassroots Women "e Initiatives for Building Community Resilience, $26^{\text {Th }}$ Annual Congress July 11-15, 2012. Pratt Institute, Ankara Turkey.

\section{AUTHORS' BIOGRAPHY}

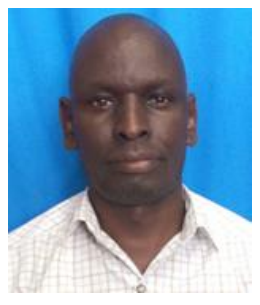

Stephen Kioko Musimba is a Doctor of Philosophy candidate in Project Planning and Management at the University of Nairobi, Kenya. He attained a Master of Arts degree in project planning at University of Nairobi, a Bachelor of Science degree in Agricultural Engineering from Egert on University, Kenya and a Diploma in Technical Education in Agricultural Engineering and Entrepreneurship at the Kenya Teacher Trainers College. He is a specialist in management currently working at the National Drought Management Authority, Kenya. He has conducted research, strategic planning, advisory and consultancy work in Arid and Semi-Arid Lands resources management for sustainable development for a number of clients. 


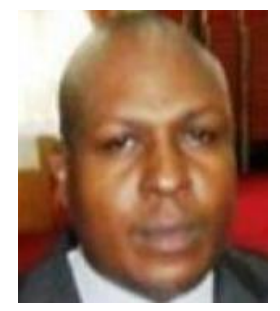

Dr. Moses Machuki Maturi Otieno obtained his Doctor of Philosophy in public administration at Mohan Lal Sukhadia University, India. He is a senior Lecturer at the University of Nairobi and has taught at Kenya Methodist University and Jomo Kenyatta University of Agriculture and Technology, as a part time lecturer in project, business management and public administration. He has supervised and offered academic tutelage to many students at masters and doctorate levels on research papers and projects. He has conducted research and consultancies in business management, human resource management, project management and development for various clients as lead researcher. He has prepared teaching curriculum and teaching guides for masters' studies and has published books and articles in refereed journals.

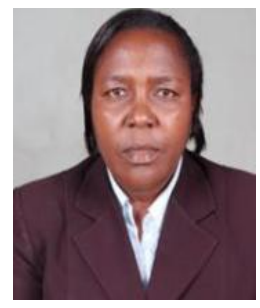

Dr. (Mrs.) Dorothy Ndunge Kyalo has a wide teaching, administration and research experience. She holds a Doctor of Philosophy Degree in Educational Administration and Planning from the Catholic University of Eastern Africa (CUEA) anda Master of Educational Administration and Planning (M.Ed) from the University of Nairobi (UoN). She is currently a senior lecturer and the director Open and Distance Education Learning Centre, University of Nairobi. She provides administrative management and leadership for undergraduate, graduate and post graduate programmes in the Centre. She is a trainer, consultant and researcher in education and project management. She has authored many books and articles on a number of topical issues in development. She has presented papers in peer conferences and academic workshops.

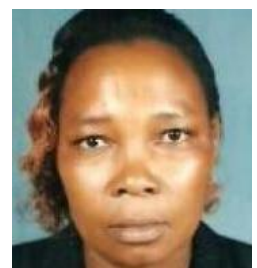

Dr. Angeline Sabina Mulwa attained a Doctorate Degree in Distance Education of the University of Nairobi and she is a lecturer in the Department of Extra-Mural Studies of University of Nairobi. She has a wide experience in academic and research work in the field on educational planning and management. She has participated in curriculum design and review in various university programmes and served as a consultant to lecturers on matters of educational interest. She has participated in developing student support systems for regular, virtual and distance learners.

Citation: Musimba, Stephen Kioko, et.al. “ Community Participation in Drought Risk Management in Kilifi County, Kenya " International Journal of Managerial Studies and Research (IJMSR), vol 6, no. 12, 2018, pp. 31-44. doi: http://dx.doi.org/10.20431/2349-0349.0612005.

Copyright: (C) 2018 Authors. This is an open-access article distributed under the terms of the Creative Commons Attribution License, which permits unrestricted use, distribution, and reproduction in any medium, provided the original author and source are credited. 